Esta publicación cientifica en formato digital es continuidad de la revista impresa ISSN-Versión Impresa 0798-1406 / ISSN-Versión on line 2542-3185Depósito legal pp
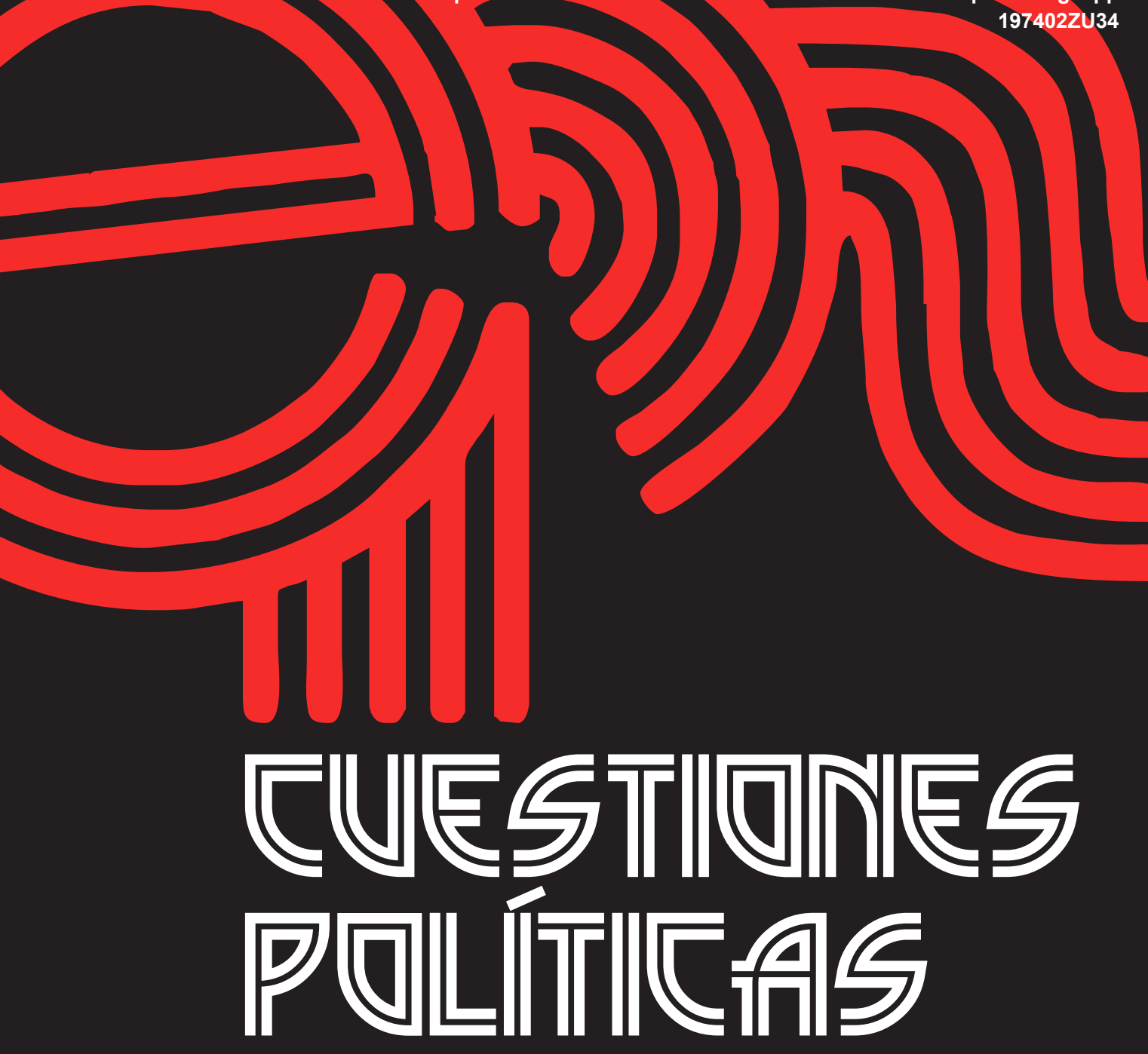

Instituto de Estudios Políticos y Derecho Público "Dr. Humberto J. La Roche" de la Facultad de Ciencias Jurídicas y Políticas de la Universidad del Zulia Maracaibo, Venezuela
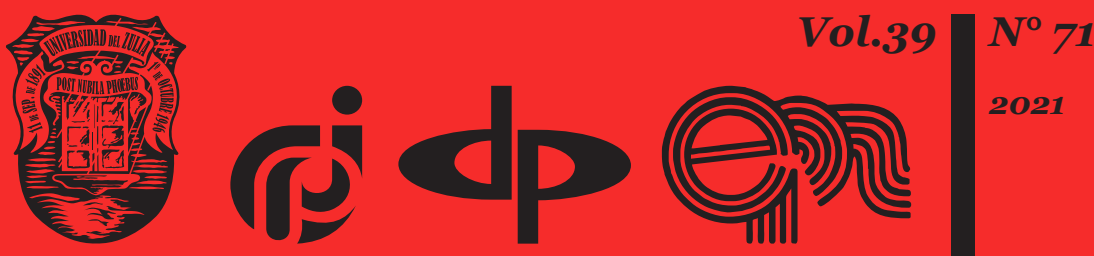


\title{
Family Rights of the Child and Their Legislative Support
}

\author{
DOI: https://doi.org/10.46398/cuestpol.3971.10
}

\author{
Vitalii M. Cherneha * \\ Liudmila V. Kuznetsova ** \\ Oleh V. Fedorchenko *** \\ Olena A. Kaminska **** \\ Sergii V. Bezpalko *****
}

\begin{abstract}
The objective of the study was to identify the legal mechanisms for the protection of the family rights of the child and to outline the main problems of their implementation. The child's family rights system was found to contain the child's intangible basic rights, which establish his or her legal status in the family. This system includes the child's right to life, name, citizenship, knowledge of his parents, care of parents, coexistence with parents, preservation of his identity and citizenship, free expression of his own views. It states that the protection of the family rights of the child and the legal relations of parents and children is based on four principles. It is determined that the practical solution of issues related to the exercise of the family rights of the child is regulated by international law, which makes it possible to resolve issues related to the legal relationship between parents and children at the inter-State level. It is concluded that perspectives on legislative support for the family rights of the child demand further empirical research, as well as a theoretical and methodological justification for determining the legal mechanisms of their practical implementation.
\end{abstract}

* Candidate of Law Sciences /PhD, Associate Professor, Department of Business Law and Corporate Law, Educational and Scientific Institute "Institute of law", State Higher Educational Institution Kyiv National Economic University named after Vadym Hetman. ORCID ID: https://orcid.org/oooo-0oo29118-6562

** Candidate of Law, Head of the Department of Public and Private Law, Rauf Ablyazov Eastern European University. ORCID ID: https://orcid.org/o0oo-0001-6810-1017

*** Candidate of History Sciences / PhD (History, head of the department of general education and sociohumanitarian subjects, Kherson Faculty of Odessa State University of Internal Affairs. ORCID ID: https://orcid.org/oooo-0003-4288-5508

**** Candidate of History Sciences / PhD (History), Associate Professor, Department of general education and socio-humanitarian subjects, Kherson Faculty of Odessa State University of Internal Affairs. ORCID ID: https://orcid.org/oooo-0001-5596-1720

***** Candidate of Law, Doctor of philosophy, Head of the Main Department of the National Police in Ivano-Frankivsk region, Associate Professor of Department of Law, Ivano-Frankivsk branch of The Open International University of Human Development «Ukraine». ORCID ID: https://orcid. org/o00o-0003-2168-06oX 
Vitalii M. Cherneha, Liudmila V. Kuznetsova, Oleh V. Fedorchenko, Olena A. Kaminska y Sergii V. Bezpalko

206

Family Rights of the Child and Their Legislative Support

Keywords: family rights of the child; parental care; child development; family responsibility; international treaties.

\section{Los derechos familiares del niño y su apoyo legislativo}

\section{Resumen}

El objetivo del estudio fue determinar los mecanismos legales para la protección de los derechos familiares del niño y esbozar los principales problemas de su aplicación. Se encontró que el sistema de derechos familiares del niño contiene los derechos básicos intangibles del niño, que establecen su estatus legal en la familia. Este sistema incluye el derecho del niño a la vida, el nombre, la ciudadanía, el conocimiento de sus padres, el cuidado de los padres, la convivencia con los padres, la preservación de su identidad y ciudadanía, la libre expresión de sus propios puntos de vista. Se establece que la protección de los derechos familiares del niño y las relaciones jurídicas de padres e hijos se basa en cuatro principios. Se determina que la solución práctica de las cuestiones relacionadas con el ejercicio de los derechos familiares del niño está regulada por el derecho internacional, lo que permite resolver cuestiones relacionadas con la relación jurídica entre padres e hijos a nivel interestatal. Se concluye que las perspectivas sobre el apoyo legislativo a los derechos familiares del niño demandan de una mayor investigación empírica, así como una justificación teórica y metodológica para determinar los mecanismos legales de su implementación práctica.

Palabras clave: derechos familiares del niño; cuidado de los padres; desarrollo infantil; responsabilidad familiar; tratados internacionales.

\section{Introduction}

The attitude to the child, to his/her natural and subjective rights, is a measure of the spirituality and humanity of society. The standard of living and civilization of the state is determined by how children live in it, the degree of public attention to them and their legal protection. Protecting the rights of the child is one of the priorities for every country, as children are not only the future of the state, but its present first. Children are the least protected part of the population, both socially and legally. Violations of the family rights of the child are common in modern society, so the state needs to create an effective legal mechanism to protect the child's rights in the 
family.

The global economic crisis is having a significant impact on children. According to Eurostat, children are the age group with the highest risk of poverty or social exclusion (Council of Europe, 2016). Although the EU is one of the richest regions in the world, its children still live-in poverty, with almost $9 \%$ of children under the age of 14 living in vulnerable families (Council of Europe, 2018). Over the last twenty years, child poverty and social exclusion have increased significantly in some EU countries. In general, younger children suffer more from poverty than other age groups. They are less prosperous than their peers but can reach their full potential at a later age.

Thirty years ago, the main international agreement on childhood, the UN Convention on the Rights of the Child, was adopted. Its provisions stipulate that a child is every human being under the age of 18 unless he or she reaches the age of majority under the law applicable to that person. The child, due to his/her physical and mental immaturity, needs special protection and care, including proper legal protection both before and after birth (OHCHR, 1996). The full and harmonious development of a child is ensured by his/her growth in a family environment, in an atmosphere of happiness, love and understanding. The UN Convention on the Rights of the Child proclaims the basic intangible rights of comprehensive development of the child: family, social, physical, informational, cultural, economic. The provisions of the Convention have helped to improve the lives of children around the world, but still not all children can enjoy their childhood to the full. Society requires not only states to fulfil their obligations and take measures to protect the rights of the child, but also parents to make a commitment so that every child can enjoy all his/her rights.

In addition to the above-mentioned Concept, the family rights of the child are reflected in other Conventions of international organizations (UN, Council of Europe, etc.). The chosen subject is topical because the problems of ensuring, protecting and defending the rights of the child in the family require a comprehensive approach to their solution, which should be based on close cooperation of different actors: the state represented by the relevant authorities, family, in which the child is brought up, and the child himself/herself as an independent person, which is gradually developed and socialized under the influence of a number of factors.

Protecting the family rights of the child through the prism of international standards has been the subject of research by many scholars. Dan (2017) studied the legal protection of the family rights of the child. Abella and Plant (2021) studied the issue of child custody through the prism of the Convention on the Civil Aspects of International Child Abduction. Rešetar (2018) researched the novelties of the Croatian legislation on the protection of the rights of the child in divorce proceedings. Lucic (2021) 
Vitalii M. Cherneha, Liudmila V. Kuznetsova, Oleh V. Fedorchenko, Olena A. Kaminska y Sergii V. Bezpalko

analysed international and European standards for compliance with Croatian legislation on the institution of special child custody. GerdtsAndresen analysed the role and place of the child in the divorce proceedings in Norway.

Churba (2021) studied parental authority and custody in cases of divorce in Spain. Nurtjahyo (2021) dealt with the parents' choice of religion in the family as a manifestation of domestic violence against children in Indonesia. Almusawi (2021) investigated the criminal liability of children and families under Iraqi law. Rochaeti and Muthia (2021) studied the legal framework of public oversight in the justice of children and parents in Indonesia. Rönsch (2020) examined German civil and social law on the temporary deprivation of parental care and the preventive protection of children's rights.

Many scientific works deal with the problems of protection of family rights of the child and their law enforcement. Thomson Henderson-Dekort et al. (2021) and Alekseeva (2020) revealed the content of the best interests of the child. Tabernacka (2021) considered mediation as an element of protection of children's rights. Nejaime (2020) reviews the constitutional rights of biological and non-biological parents. Gerber et al. (2020) examined the institution of legal representation of the child in foster care. Abbasi and Mahmoodian (2020) studied the protection of children's rights in the context of reproductive technology legislation. Butryn-Boka (2018) revealed the content of the international experience of implementing spousal alimony obligations. Kašný (2021) researched the family upbringing of children on the basis of religious and legal norms.

So, the aim of this study is to analyse the legal protection of family rights of the child and outline the main problems of their enforcement. This aim provides for the following objectives:

- reveal the content of the family rights of the child through the prism of international legal norms in the field of protection of the rights of the child and the state policy of protection of the rights of the child.

- determine the classification of family rights of the child and the principles on which the system of protection of the rights of the child in the family is based.

- identify the main problems of law enforcement of family rights of the child and suggest ways to solve them. 


\section{Methods and materials}

Empirical and theoretical methods of scientific knowledge were used to study this topic. Empirical knowledge reflects the object of study (family rights of the child) from the standpoint of external relations (legislative support, legal relations). Next, we consider scientific, legal, and practical information on the protection of family rights of the child and reveal the legal nature of the rights of the child in the family, their systematization and classification through analysis, synthesis and logical approach. Theoretical knowledge of the family rights of the child reflects this subject of research from the perspective of universal internal essential connections and regularities which are covered by rational processing of empirical data. The combination of these two methods generates an empirical interpretation of the theory and theoretical interpretation of empirical data, as well as provides comprehensive coverage of the legal protection of the rights of the child in the family.

The main materials in this study are international legal acts: the UN Convention on the Rights of the Child; Convention on the Civil Aspects of International Child Abduction; European Convention on the Exercise of Children's Rights; Convention on Jurisdiction, Applicable Law, Recognition, Enforcement and Co-operation in Respect of Parental Responsibility and Measures for the Protection of Children; Convention on Contact concerning Children; Convention on the Recovery Abroad of Maintenance; Convention on the Recognition and Enforcement of Decisions Relating to Maintenance Obligations; European Convention on Recognition and Enforcement of Decisions Concerning Custody of Children and on the Restoration of Custody of Children; European Convention on the Legal Status of Children Born out of Wedlock; Council of Europe Convention on Protection of Children against Sexual Exploitation and Sexual Abuse; European Convention on the Adoption of Children (revised); Convention on Protection of Children and Co-operation in Respect of Intercountry Adoption.

The information and empirical background of the study is statistics of the UN and the Council of Europe, generalization of practical application of international law in the field of family rights of the child, practical activities of social services for children's rights, reference books, publications in periodicals.

\section{Results}

The provisions of the UN Convention on the Rights of the Child guarantee every child the right to have a name, know his/her parents and parental care (OHCHR, 1996). The system of family rights of a child includes his/ 
Vitalii M. Cherneha, Liudmila V. Kuznetsova, Oleh V. Fedorchenko, Olena A. Kaminska y Sergii V. Bezpalko

her rights to life, name, and citizenship, to know his/her parents, parental care, living with parents, preserving his/her identity and citizenship, free expression of his/her own views (Figure 1).

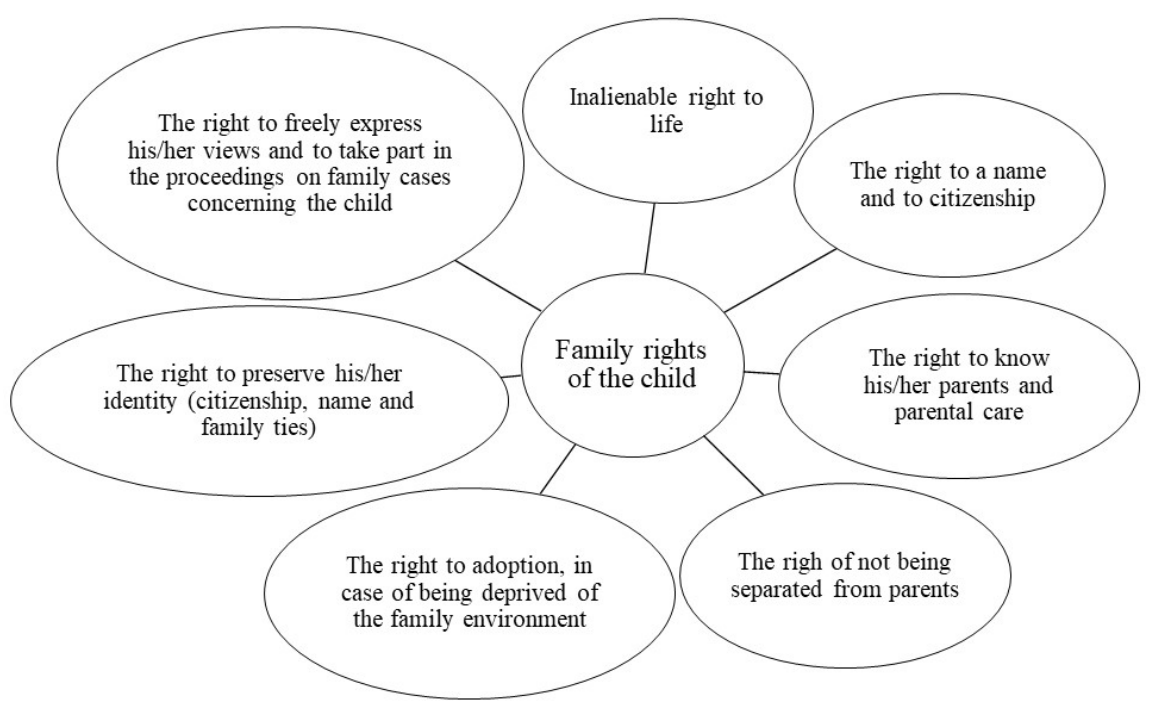

\section{Figure 1. Classification of family rights of the child Source: author's own development based on (OHCHR, 1996).}

According to Article 6 of the UN Convention on the Rights of the Child, every child has the inalienable right to life, necessary for physical, mental, spiritual, moral and social development. The state ensures the maximum possible survival and healthy development of the child (OHCHR, 1996). The right to life belongs to the fundamental rights of the child, and no one has the right to deprive him/her of it.

Children must be registered after birth and have the right to a name and citizenship from birth. The state ensures the exercise of these rights in accordance with the law (OHCHR, 1996, Article 7). Parents are obliged to give the child a name and surname in accordance with current legislation and religion, as well as to register the child with the appropriate government agency.

Article 8 of the UN Convention on the Rights of the Child gives every child the right to preserve his/her identity, including nationality, name and family ties, as required by law, without unlawful interference. In the event that the child is illegally deprived of part or all of its elements, the state 
undertakes to provide it with the necessary assistance and protection in order to regain his/her identity as soon as possible (OHCHR, 1996).

Every child has the right to know his/her parents and the right to their care (OHCHR, 1996, Article 7). More and more children are being born out of wedlock, and the European Community has adopted the European Convention on the Legal Status of Children Born out of Wedlock to resolve legal disputes concerning such children. According to the provisions of this Convention, maternity in respect of each child born out of wedlock is based only on the birth of a child (Article 2), and paternity can be confirmed or established by voluntary recognition or by court order (Article 3) (WORLDLII, 2000). The rights of the parents of such children have the same responsibilities to support the children as they would have had born in marriage. Besides, the European Convention on the Legal Status of Children Born out of Wedlock declares voluntary recognition of paternity, which may be the subject of appeal only if the person who wishes to recognize or recognized the child is not its biological parent (Article 4) (WORLDLII, 2000).

Every year, more and more families become parents with the help of reproductive technologies, which have recently become more developed and effective. The use of such technologies has raised questions about legal regulation in the context of parental rights.

According to the World Health Organization, reproductive rights are based on the recognition of the fundamental right of all couples and individuals to freely and responsibly decide the number, time and birth of their children and the opportunity to have information and means to do so (WHO, 2017). Reproductive rights are part of the human rights system as defined by the Universal Declaration of Human Rights. Recognition of maternity and paternity of children born of reproductive technologies in different countries is special, states interpret the concept of reproductive rights differently and establish different levels of their legislative support. Therefore, the practice of recognizing maternity and paternity through the prism of reproductive rights is realised at the advocacy level.

Parental care is aimed at the development and raising of the child. Parents at their own discretion choose methods that are sufficient for the comprehensive development of their children and are responsible for the upbringing of the child. To establish the institution of parental responsibility, the state creates a system of public authorities in the field of protection of children's rights (including social protection of children, adoption, custody, juvenile service, etc.). The establishment of such an institution of parental responsibility is provided for in the Convention on Jurisdiction, Applicable Law, Recognition, Enforcement and Co-operation in Respect of Parental Responsibility and Measures for the Protection of Children ( $\mathrm{HCCH}, 2002)$. 
Vitalii M. Cherneha, Liudmila V. Kuznetsova, Oleh V. Fedorchenko, Olena A. Kaminska y Sergii V. Bezpalko

In general, the Convention covers issues of protection of children, parental responsibility, custody, in particular, the right to determine the child's place of residence, as well as the right to communication, care and similar institutions, placement of a child in a foster family or custody, supervision by a public authority for a child in custody, as well as taking measures to protect the person or property of the child (Article 3). However, the Convention does not apply to: the establishment or appeal of a parent-child relationship; adoption decisions, pre-adoption measures, or revocation or invalidity of adoption; name and surname of the child; acquisition of full legal capacity; maintenance obligations; trust or inheritance; social security; general government measures on education or health care; measures resulted from punishable offenses committed by children; decisions on the right to asylum and immigration (Article 4).

Caring for children requires both spiritual, moral, and material resources. The provisions on the maintenance obligations of parents for the development of a child are defined by the Convention on the Recognition and Enforcement of Decisions Relating to Maintenance Obligations and the Convention on the Recovery Abroad of Maintenance (HCCH, 1996; HCCH, 1998).

The provisions of the Convention on the Recognition and Enforcement of Decisions Relating to Maintenance Obligations allow for the recognition and enforcement of maintenance decisions made in other states, regardless of whether the decision is made by a court or an administrative authority. Maintenance obligations may arise from family relationships, maternity, paternity, marriage, or family ties. The Convention applies to decisions on maintenance between the recipient of alimony and the payer of alimony, or the payer of alimony and the public authority that recovers funds paid to the recipient of alimony (HCCH, 1996).

In order to facilitate the recovery of alimony in cases where the plaintiff and the defendant reside in different states, the Convention on the Recovery Abroad of Maintenance establishes the mechanism of transfer of the request for recovery of alimony from the defendant, transfer of court decisions to the contracting state in which the decision on execution shall be made.

Unfortunately, the manifestation of parental care can have negative sides: domestic violence against children, sexual violence, bullying and other manifestations. The UN Convention on the Rights of the Child obliges states to take legislative, administrative, social and educational measures to protect the child from all forms of physical and psychological violence, abuse, lack of care, negligent and brutal treatment and exploitation, including sexual abuse, by parents, legal custodians or any other person who cares for the child (OHCHR, 1996, Article 19). In order to prevent sexual exploitation and sexual abuse of children, including by parents, and to combat these phenomena, the Council of Europe has adopted the 
Council of Europe Convention on the Protection of Children against Sexual Exploitation and Sexual Abuse (Council of Europe, 2007).

Every child has the right not to be separated from his/her parents. The state ensures that the child does not get separated with the parents against his/her will, except when the competent authorities, in accordance with a court decision, determine that such separation is necessary in the best interests of the child under the applicable law and procedures (OHCHR, 1996, Article 9).

The child and his/her parents have the right to establish and maintain regular contact with each other. Such contact may be limited or prohibited only when it is necessary in the best interests of the child [10, Article 4]. Identifying general principles applicable to contact between children and their parents, as well as other persons with family ties to children, appropriate precautions, and safeguards to ensure proper contact and immediate return of children after contact, as well as the establishment of cooperation between the competent authorities is the subject of the Convention on Contact concerning Children (OHCHR, 2003).

In order to ensure the well-being of the child in the event of the loss of the family environment, the state undertakes to take measures for his/ her adoption and custody. The European Convention on Recognition and Enforcement of Decisions concerning Custody of Children and on Restoration of Custody of Children provides an opportunity to introduce measures that ensure wide recognition and enforcement of decisions regarding child custody, guarantee the rights of parents' access to the child, which is a normal consequence of the right to custody, ensure proper resolution of problems that arise when children are illegally moved across the state border; and establishes mechanisms for the restoration of custody of children in cases of its arbitrary termination, which will enhance the protection of children and the establishment of legal cooperation between the competent authorities of the Contracting States (Council of Europe, 1980).

For the full and harmonious development of his/her personality, a child must grow up in a family environment, in an atmosphere of happiness, love and well-being. In the event of a loss of family environment, it is a priority for each state to take appropriate measures to ensure that the child is brought up in a family. The issue of child adoption, including interstate adoption, is regulated by the European Convention on the Adoption of Children (Revised) and the Convention on Protection of Children and Co-operation in Respect of Intercountry Adoption. These international treaties establish common principles, regulate the institution of adoption and differences in adoption processes and legal consequences, as well as promote guarantees that interstate adoption is carried out in the best interests of the child and in compliance with all fundamental rights recognized in international law (Council of Europe, 2008; HCCH, 1993). 
Vitalii M. Cherneha, Liudmila V. Kuznetsova, Oleh V. Fedorchenko, Olena A. Kaminska y Sergii V. Bezpalko

The Convention on the Civil Aspects of International Child Abduction is aimed at protecting children from illegal movement ( $\mathrm{HCCH}, 1993)$. It establishes a mechanism to ensure the return of illegally removed or detained children to their country of residence.

According to international standards, every child has the right to freely express his/her views and to take part in court proceedings concerning relevant family cases. Article 12 of the UN Convention on the Rights of the Child says that States shall ensure that a child who is able to express his/ her views has the right to express those views freely on all matters affecting the child, with due regard to the child's age and maturity. That is, children are given the opportunity to be heard in any judicial or administrative proceedings concerning them, directly or through a representative or appropriate body in the manner prescribed by the procedural rules of national law (OHCHR, 1996).

The subject of the European Convention on the Exercise of Children's Rights is ensuring the best interests of children, that is support for their rights, granting them procedural rights and facilitating the exercise of these rights by ensuring that children are personally or through other persons or bodies informed and allowed to participate in the consideration of judicial proceedings in cases concerning them (Council of Europe, 1996, Article 1). Family cases considered by a judicial authority are related to the exercise of parental responsibility, such as the child's place of residence and access to the child.

According to the European Convention on the Exercise of Children's Rights, every child who has a sufficient level of understanding is given the right to: be informed and express his/her views during the proceedings (Article 3); submit in person or through other persons or bodies a request for the appointment of a special representative during the consideration of cases concerning him/her by a judicial body (Article 4); request assistance from the person of his/her choice in expressing their opinion (Article 5); apply independently or through other persons or bodies for the appointment of an individual representative, and in appropriate cases - a lawyer (Article 5); appoint his/her representative (Article 5); exercise some or all of the rights of the parties in such a process (Article 5) (Council of Europe, 1996).

In the field of family relations between children and parents, the state plays a significant role in ensuring the protection of the rights of the child in the family and family upbringing of children with the possibility of their full spiritual and physical development. The main tasks and guarantees of the state to protect the family rights of the child are shown in Figure 2. 


\section{State obligations to protect the family rights of the child}

- The state provides appropriate conditions for the healthy development of the child and his/her survival

- The state shall take measures to ensure the protection of the child from all forms of discrimination or punishment by parents or other family members

- The state provides the child with proper protection and care that is necessary for his/her well-being

- The state respects the responsibility, rights and responsibilities of parents to manage the child in the exercise of its right in a manner consistent with the child's developing abilities

- The state takes measures for the child to acquire name and citizenship

- The state ensures that the child is not sepatared from his/her parents

- The state respects the right of the child and his/her parents to leave any country, including his/her own, and to return to his/her country

- The state takes measures to recognize the principle of universal and equal responsibility of both parents for the upbringing and development of the child

- The state takes measures to protect the child from all forms of physical and psychological violence, abuse, lack of care or negligent and brutal treatment and exploitation, including sexual abuse, by parents

- The state undertakes to facilitate the adoption of a child who is temporarily or permanently deprived of a family environment

- The state takes measures to find the parents of any refugee child for their reunification

- The state takes measures to ensure the level of a full andadequate life of the child and to provide assistance to parents for his/her development

Figure 2. Powers of the state to protect the family rights of the child. Source: author's own development based on (OHCHR, 1996).

The system of protection of family rights of the child and legal relations of parents and children is based on four principles (Figure 3).

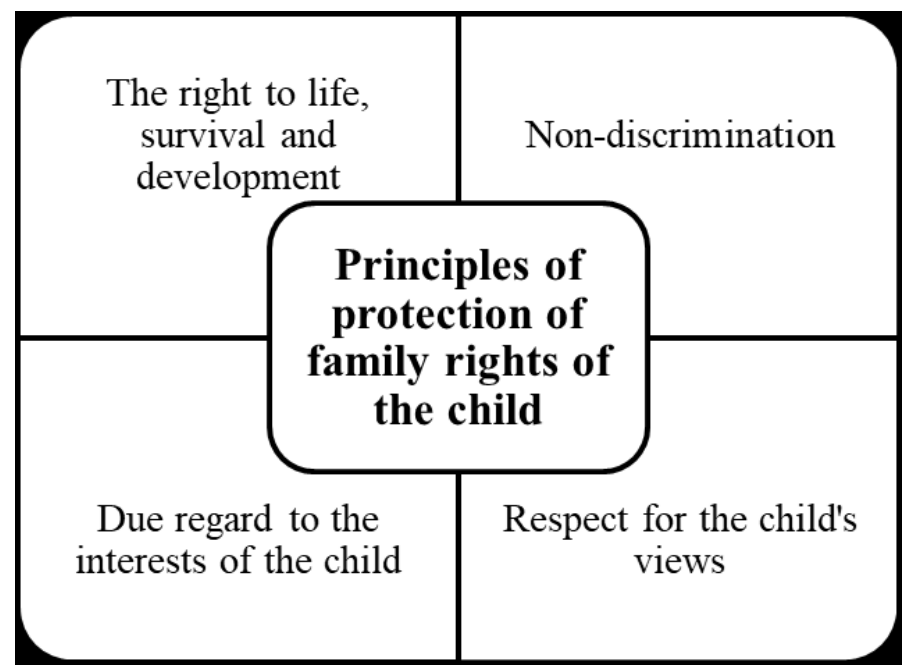

Figure 3. Principles of protection of family rights of the child Source: author's own development based on (OHCHR, 1996). 
Vitalii M. Cherneha, Liudmila V. Kuznetsova, Oleh V. Fedorchenko, Olena A. Kaminska y Sergii V. Bezpalko

Non-discrimination of the child is guaranteed by Article 2 of the UN Convention on the Protection of the Rights of the Child, which provides that the state ensures all the rights of the child without any discrimination regardless of race, color, sex, language, religion, political or other beliefs, national, ethnic or social origin, property status, state of health and birth of the child, his/her parents. The state takes measures to ensure the protection of the child from all forms of discrimination or punishment based on the status, activities, views or beliefs of the child and the child's parents (OHCHR, 1996).

The right to life, survival and development of a child, as well as the protection and care of the child is guaranteed by the state, which is necessary for his/her well-being, taking into account the rights and responsibilities of his/her parents, custodians or other persons before the law. Such rights are guaranteed through legislative and administrative measures (OHCHR, 1996, Article 3).

Respect for the views of the child is guaranteed by the state, which provides free expression of his/her own views and participation in court proceedings concerning the child (OHCHR, 1996, Article 6).

Taking into account the interest of the child is a priority for parenting and a priority of public or private institutions in the field of social security, courts, administrative or legislative bodies (OHCHR, 1996, Article 3).

\section{Discussion}

The family rights of the child have clear and inalienable links with private international law. The practical solution of issues related to the exercise of family rights of the child is regulated by international treaties in the field of protection of family rights, which allow to address level issues related to parental relations, parental responsibility, custody, adoption, as well as recognition and enforcement of court decisions regarding the protection of children's rights at the interstate level.

Analysis of international legislation in the field of protection of family rights of the child, as Dan (2017:56) notes, gives grounds to argue that foreign experience is important because it demonstrates, first of all, the variability of legal models for ensuring, protecting and defending the rights of the child used in different countries, as well as the effectiveness or ineffectiveness of their implementation in public practice. However, according to the scientist, there are no ways of state and legal development that are completely unified for different societies.

Analysing international agreements in the field of family rights of children, Gerdts-Andresen (2021a: 563-564) notes the inconsistency of 
their rules with the provisions of national law in terms of custody and competence of social authorities to protect the rights of children. Abella (2021: 352-353) and Uchitel et al. (2019: 19-20) also note the differences between international standards for custody and protection of children's rights with national provisions. Butryn-Boka (2018: 44) argues that the institution of child support has its own characteristics in each country, which are established by a combination of international and national legislation in the field of protection of children's rights. The family right of a child to know his/her parents is realized through the establishment of paternity and maternity, which, according to Nejaime (2020: 261), is not always consistent with constitutional rights and provisions of international law.

The legislator must create conditions for the freedom to choose the individual parenting of the child, which, according to Rönsch (2020), will help maintain the child's well-being, reduce domestic violence against the child in the family and significant child abuse. Appropriate conditions for the upbringing and development of children, as Almusawi (2021) emphasized, are based on the moral behaviour of parents, because in case of their immorality, children become the object of criticism and harassment by society for the actions of parents. According to Thomson (2021: 277279), the best interests of the child are a manifestation of social justice and stability, the principles of which must be guaranteed for every family. Realization of the best interests of the child, according to HendersonDekort et al. (2021: 78-80), Alekseeva (2020: 48-49), should be based on access to benefits aimed at the full development of the child, and in case of deprivation of the family environment - independent child's participation in the consideration of custody issues.

In order to properly protect the rights of the child in case of divorce of parents, as Rešetar (2018:63-64) noted, the child must act as a separate party in the divorce process, accompanied by a special custodian - a representative of the child's interests. Lucić (2021: 97-99) believes that the powers of such a representative custodian of the child should be clearly defined at the legislative level.

According to Gerdts-Andresen (2021b), to address the issue of custody of a child in a divorce proceeding, the court must take into account the opinion of a child above 7 years of age. And in order for the child's opinion to be impartial in deciding custody, Abella (2021: 351-352) offers to give the child to the authorized body at his/her place of residence for the period of the divorce process. Such relocation of a child, as the researcher argues, will allow him/her to make his/her own choice of living with one of the parents without pressure and will settle the conflict between parents for custody of the child, which may lead to kidnapping of the child by one parent in the future (Gerdts-Andresen and Aarum Hansen, 2021). 
Vitalii M. Cherneha, Liudmila V. Kuznetsova, Oleh V. Fedorchenko, Olena A. Kaminska y Sergii V. Bezpalko

Jabbaz Churba (2021: 351-352) identifies three reasons that impair the rights of the child in the event of divorce: the lack of established rules on custody of the child before the divorce of the parents; the divorce process is a manifestation of hidden gender-based violence and gender stereotypes; parental authority is a manifestation of conditional violence after divorce.

Tabernacka (2021:89-90) believes that the use of pre-trial proceedings on illegal actions against children, will resolve conflicts, understand the child's legal status and serve as an educational element in the awareness of his/her own rights and responsibilities. According to Rochaeti and Muthia (2021: 293-295), improving the protection of children's family rights can be achieved through public control in the form of public involvement in litigation of children.

The influence of religion on the upbringing of a child in the family can be both positive and negative. Positive will be manifested in the case of the implementation of religious canons in the norms of the laws on which parents raise children, shape their worldview. In this case, as Kašný (2021: 19-21) argues, it is better to cover the legal background and structure of the family from a religious perspective in the provisions of the articles of regulations. Negative is manifested in the case of discordance between parents in the choice of religion. In this case, Nurtjahyo (2021) believes that when in religious families one parent changes his/her religion, it can lead to conflicts between parents and domestic violence against children.

According to Gerber et al. (2020), the institute of legal representatives of the child in foster families should be introduced to improve the child's stay in foster care. Its introduction in comparison with the independent lawyer will promote rapprochement of the child in foster families. The effectiveness of such representatives of parenthood will depend on the establishment of unity of representation, the accumulation of interdisciplinary practices and the maximum attention paid to the child for his/her well-being.

Abbasi and Mahmoodian (2020) studied the protection of children's rights in the context of reproductive technology legislation, proposing to establish a clear mechanism to protect the rights not only of parents who became parents through such technologies, but also the child.

As a result of the doctrinal analysis of the specified problems of protection of family rights of the child, we can note that researchers consider it reasonable to further study of protection of the rights of the child in a family, develop effective recommendations of their practical implementation that would adjust the content and directions of the development of legal mechanisms for the protection of the rights of parents and children. 


\section{Conclusion}

The system of protection of family rights of the child is a set of guarantees of observing family rights of the child and their protection concerning development and education of children in a family, enshrined in the international and national regulations in the field of protection of family rights. The full development of the child is based on respect for the child's right to life, name, citizenship, knowledge of his/her parents, parental care, living with his/her parents, preservation of his/her identity and citizenship, and free expression of his/her views. Ensuring the family rights of the child in the system of their protection is based on four principles: respect for the views of the child, non-discrimination, taking into account the interests of the child, as well as the children's right to life, survival and development.

The practical application of the family rights of the child is regulated by international treaties, which resolve issues related to the legal relationship between parents and children and the activities of the state in the field of protection of the rights of the child at the interstate level. Problems of ensuring the protection of family rights of the child are related to the delimitation of rights and responsibilities of parents for the upbringing and development of their children while guaranteeing the best interests of the child, recognition of maternity/paternity, parental responsibility, introduction of custody, adoption, child support and authorised representatives of the child.

The prospect of further research is to develop mechanisms for the enforcement of family rights of the child, aimed at educating the individual in harmony and well-being of the family. Therefore, we see further prospects in the empirical study, as well as theoretical and methodological justification of effective legal mechanisms for implementing the principles of protection of children's rights in the family and the effectiveness of the system of state bodies authorized to protect family rights of the child.

\section{Bibliographic References}

ABBASI, Mikaell; MAHMOODIAN, Nilson. 2020. "Research Paper: Jurisprudence-Legal Consideration of Single-Status Childbearing" In: International Journal of Medical Toxicology and Forensic Medicine. Vol. 10, No. 3, pp. 325-353.

ABELLA, Justice Rosalie; PLANT, Jocelyn. 2021. "The Hague Convention and Transnational Custody Disputes” In: Family Court Review. Vol. 2, No. 59, pp. 350-370. 
Vitalii M. Cherneha, Liudmila V. Kuznetsova, Oleh V. Fedorchenko, Olena A. Kaminska y Sergii V. Bezpalko

ALEKSEEVA, Oleksandra. 2020. "The place and role of the principle of Child Best Interests in the realization of parental rights and responsibilities" In: Theoretical and empirical scientific research: concept and trends. Vol. 4, pp. 48-49.

ALMUSAWI, Bassim Jameel. 2021. "Criminal protection of the family in the Iraqi legislation” In: Hasanuddin Law Review. Vol. 1, No. 7, pp. 21-30.

BUTRIN-BOKA, Natalia. 2018. "International Experience of Implementation of Spousal Alimony Obligations in Ukraine" In: Current issues of domestic jurisprudence. Vol. 4, pp. 42-44.

COUNCIL OF EUROPE. 1980. European Convention on Recognition and Enforcement of Decisions concerning Custody of Children and on Restoration of Custody of Children. Available online. In: https://rm.coe. int/1680078bo9. Consultation date: 18/10/2020.

COUNCIL OF EUROPE. 1996. European Convention on the Exercise of Children's Rights. Available online. In: https://rm.coe.int/europeanconvention-on-the-exercise-of-children-s-rights/1680a40f72. Consultation date: 17/10/2020.

COUNCIL OF EUROPE. 2007. Council of Europe Convention on the Protection of Children against Sexual Exploitation and Sexual Abuse. Available online. In: https://rm.coe.int/1680084822. Consultation date: $16 / 10 / 2020$.

COUNCIL OF EUROPE. 2008. European Convention on the Adoption of C Available online. In: hildren (Revised). Available online. In: https:// rm.coe.int/1680084823. Consultation date: 17/10/2020.

COUNCIL OF EUROPE. 2016. Challenges to children's rights today: What do children think? Available online. In: https://edoc.coe.int/en/childrens-rights/7205-challenges-to-children-s-rights-today-what-do-childrenthink.html. Consultation date: 17/10/2020.

COUNCIL OF EUROPE. 2018. Children. Available online. In: https://www.coe. int/en/web/compass/children. Consultation date: 15/10/2020.

DAN, Gregory. 2017. "Legal support of children's rights: international and domestic experience" In: Criminological theory and practice: experience, current problems and ways to solve them: interuniversity materials. scientific-practical round table. Pp. $48-52$.

GERBER, Lucas; GUGGENHEIM, Martin; PANG, Yuk; ROSS, Timothy; MAYEVSKAYA, Yana; JACOBS, Susan; PECORA, Peter. 2020. "Understanding the effects of an interdisciplinary approach to parental 
representation in child welfare" In: Children and Youth Services Review. Vol.116, pp. 51- 62.

GERDTS-ANDRESEN, Tina. 2021a. "A scoping review of when and how a child's view is weighted in decision-making processes in law proceedings" In: Children and Youth Services Review. Vol. 129, pp. 61-73.

GERDTS-ANDRESEN, Tina. 2021b. "Childs' right to family life when placed in public care; an analysis of whether current Norwegian practice is in systematic contradiction to human rights" In: International Journal of Children's Rights. Vol. 3, No. 29, pp. 563-588.

GERDTS-ANDRESEN, Tina; AARUM HANSEN, Heidi. 2021. "How the child's views is weighted in care order proceedings" In: Children and Youth Services Review. Vol. 129.

HCCH. 1993. Convention of 29 May 1993 on Protection of Children and Cooperation in Respect of Intercountry Adoption. Available online. In: https://www.hcch.net/en/instruments/conventions/full-text/?cid=69. Consultation date: $15 / 10 / 2020$.

HCCH. 1996. Convention of 2 October 1973 on the Recognition and Enforcement of Decisions Relating to Maintenance Obligations. Available online. In: https://www.hcch.net/en/instruments/conventions/full-text/?cid=85. Consultation date: 15/10/2020.

HCCH. 1998. Convention on the Recovery Abroad of Maintenance, New York 20 June 1956. Available online. In: https://assets.hcch.net/docs/30c3a5d74a53-4a6c-aef5-226600585cc3.pdf. Consultation date: 17/10/2020.

HCCH. 2001. Convention of 25 October 1980 on the Civil Aspects of International Child Abduction. Available online. In: https://www.hcch. net/en/instruments/conventions/full-text/?cid=24. Consultation date: 19/10/2020.

HCCH. 2002. Convention of 19 October 1996 on Jurisdiction, Applicable Law, Recognition, Enforcement and Co-operation in Respect of Parental Responsibility and Measures for the Protection of Children. Available online. In: https://www.hcch.net/en/instruments/conventions/fulltext/?cid=70. Consultation date: 17/10/2020.

HENDERSON-DEKORT, Emmie; SMITS, Veronica; VAN BAKEL, Hedwig. 2021. "The meaningful participation and complex capacities of children in family law: Based on transdisciplinary perspectives and articles of the united nations convention on the rights of the child" In: International Journal of Children's Rights. Vol. 1, No. 29, pp. 78-98. 
Vitalii M. Cherneha, Liudmila V. Kuznetsova, Oleh V. Fedorchenko, Olena A. Kaminska y Sergii V. Bezpalko

JABBAZ CHURBA, Marcela. 2021. "Custody and Care of Children in Spain: Can the Two Rights be Reconciled?” In: Feminist Legal Studies. Vol. 3, No. 29, pp. 351-373.

KAŠNÝ, Jiří. 2021. "Openness to the family: The new testament foundations of family law” In: Studia Theologica. Vol. 2, No. 23, pp. 19-48.

LUCIĆ, Nataša. 2021. "Child's special guardian - International and European expectations and Croatian reality" In: Balkan Social Science Review. Vol. 17, pp. 97-117.

NEJAIME, Douglas. 2020. “The constitution of parenthood" In: Stanford Law Review. Vol. 2, No. 72, pp. 261-380.

NURTJAHYO, Lidwina Inge. 2021. "The issue of rights of religious freedom in some domestic violence cases in Indonesia” In: Religions. Vol. 9, No. 12, pp. 733-744.

OHCHR. 1996. Convention on the Rights of the Child. Available online. In: https://www.ohchr.org/en/professionalinterest/pages/crc.aspx. Consultation date: 16/10/2020.

OHCHR. 2003. Convention on Contact concerning Children. Available online. In: https://www.ohchr.org/documents/professionalinterest/crc.pdf. Consultation date: 15/10/2020.

REŠETAR, Branka. 2018. "The New Divorce Legislation in the Republic of Croatia under the Influence of Psychology, Sociology, and International Law" In: International Journal of Law, Policy and the Family. Vol. 1, No. 32, pp. 63-79.

ROCHAETI, Nur; MUTHIA, Nurul. 2021. "Socio-legal study of community participation in restorative justice of children in conflict with the law in Indonesia” In: International Journal of Criminology and Sociology. Vol. 10, pp.293-298.

RÖNSCH, Hendrik. 2020. "Effectiveness of laws and policies governing permissive parenting in pursuit of the reduction of severe child abuse in Germany" In: Children and Youth Services Review. Vol. 119, pp. 55-64.

TABERNACKA, Magdalena. 2021. "The legal situation of a child in mediation in light of the regulations of international law" In: International Comparative Jurisprudence. Vol. 1, No. 7, pp. 88-99.

THOMSON, Michael. 2021. "A capabilities approach to best interests' assessments” In: Legal Studies. Vol. 2, No. 41, pp. 276-293. 
UCHITEL, Julie; ALDEN, Errol; BHUTTA, Zulfiqar; GOLDHAGEN, Jeffrey; PRADHAN NARAYAN, Aditee; RAMAN, Shanti; SPENCER, Nick; WERTLIEB, Donald; WETTACH, Jane; WOOLFENDEN, Sue; MIKATI, Mohamad. 2019. "The rights of children for optimal development and nurturing care" In: Pediatrics. Vol. 61, No. 144, pp. 19-48.

WHO. 2017. Gender and reproductive rights. Available online. In: https:// web.archive.org/web/20090726150133/http://www.who.int// reproductive-health/gender/index.html. Consultation date:16/10/2020.

WORLDLII. 2000. European Convention on the Legal Status of Children Born out of Wedlock. Available online. In: http://www.worldlii.org/int/other/ COETSER/1975/1.htlm. Consultation date: 18/10/2020. 

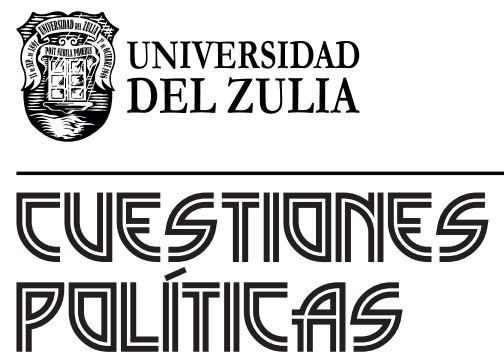

Vol. 39 N $^{\circ} 71$

Esta revista fue editada en formato digital y publicada en diciembre de 2021, por el Fondo Editorial Serbiluz, Universidad del Zulia. Maracaibo-Venezuela 